\title{
Indigenous Peoples and the Singular Socio-Political Trajectory of the Mbororo in Ngaoui Subdivision (Cameroon) ${ }^{1}$
}

\author{
ASSANA \\ Senior Lecturer/Researcher in Political Science \\ (Department of Political Science, Faculty of Law and Political Science/ University of \\ Ngaoundere-Cameroon) \\ E-mail: assana_a@yahoo.fr
}

Received: Dec. 1, 2020 Accepted: Dec. 31, 2020 Online published: Feb. 25, 2021

doi:10.5296/jpag.v11i1.18017～URL: https://doi.org/10.5296/jpag.v11i1.18017

\begin{abstract}
This study concerns the Mbororo of Ngaoui Subdivision (Cameroon). And for some good reasons: unlike those of Chad, Central African Republic (CAR) or certain regions of Cameroon such as the West, the Far North, the North and the East, where they constitute a vulnerable, dominated and marginalized group, the Mbororo of Ngaoui have succeeded in establishing themselves as a dominant group. This is due to their sedentarization caused by the boom in the cattle market, and accelerated by cross-border crimes in the 1970s. This sedentarization takes place through the diversification of their economic activities, openness to Christianity and access to health and educational infrastructures on one hand, and the relative possession of traditional power and above all, their central position in local politics on the other hand. By relying on the theory of the coloniality of power and empirical data collected in the localities where the Mbororos are highly established and their herds which are Djohong and Ngaoui. This contribution aims at analysing the singular socio-political trajectory of this Fulani fraction which does not respond to the definitional and identifying criteria enshrined in the international and Cameroonian conceptions, which makes them, indigenous, marginal and vulnerable populations respectively.
\end{abstract}

Keywords: Indigenous people, Sedentarization, Domination, Mbororo, Ngaoui Subdivision (Cameroon)

\footnotetext{
${ }^{1}$ I express my gratitude to the Alexander Von Humboldt Foundation for offering me a 06-month fellowship in Germany which enabled me to write this article. I am also grateful to the Arnold Bergstraesser Institut (ABI) in Freiburg who served as my home laboratory. Finally, I am grateful to Mouiche Ibrahim, who has been a discussion partner and an attentive reviewer. May all find here the expression of my gratitude
} 


\section{Introduction}

Available scientific production on the Mbororo suggests two dominant discourses from different angles. The first, inspired by historical and geographical approaches, tends to apprehend the Mbororos as vulnerable, marginalized and dominated social categories (see Bonne Mbang, 2005; Kossoumna Libaa, 2008; Seignobos, 2011; Mimche, Michaela, 2012: pp.145-167; Tidjani, 2015; Kamdem, 2017; Tidjani 2018; Bonne Mbang, Owona Ndounda, 2019: pp.38-61). The second, much more dynamic, and favoured by political science, turn to consider the political awakening and the exacerbation of the awareness of the socio-political marginalization of this social category in the movement of democratization, liberalization and decentralization (Davis, 1995: pp.213-228; Michaela, 2008, pp. 540-560; Mouiche, 2011 and 2012). The general tendency is a primary focus on the situation of non-dominance of the Mbororo. The socio-political trajectory of the Mbororo of Ngaoui Subdivision that we are studying now is rather singular, going against the grain of the paradigm of vulnerability and marginality; it's being understood that we are dealing with a Mbororo category which has imposed its domination on other populations. This piece of work is a new milestone, among the existing literature on the socio-political situation of this Fulani fraction.

The locality of Ngaoui was founded by a shepherd named Bouba Labi, around the 1960s and 1970s. This Mbororo shepherd, transhumant in the outskirts of the village of Djohong, was welcomed by Doumba wanla Guedeyi (1928/1963), the Gbaya traditional leader of the said village. This shepherd asked the indigenous Gbaya chief for permission to graze the oxen in the vicinity of Djohong. The Lamido gave his consent there by ceding part of his territory for him. It is this area that bears the name of Ngaoui. The fertile nature of this area has motivated these people to settle in Ngaoui, where they built their shepherds' huts ${ }^{2}$ (Interview of 05/06/2019 in Djohong). Nevertheless, the locality of Ngaoui seems to have been long occupied by Mboum farmers before the Mbororo came to settle. The anteriority of the Mboum settlement in this locality can be reconstructed from the analysis of the toponymy of Ngaoui. The name Ngaoui etymologically derives from Mboum Mbere language: "ngao" meaning "mountain". The village therefore gets its name from its position at the foot of the mountain. It is one of the four (4) Sub-divisions found in the Mbere Division, Adamawa Region of (Cameroon). It is located in the northeast of this Division. It is bordered to the northwest by Djohong Subdivision, at the east by the Republic of Central Africa, at the south and south-east by the Meiganga Subdivision. It was created by Presidential Decree $N^{\circ}$ 95/085 of April 25, 1995. In 2012, the population of Ngaoui is estimated at 201,600 inhabitants out of a density of 11.86 inhabitants per $\mathrm{km}^{2}$ (Socio-economic Report of the Mbere division in the year 2018, 2019, p.213). Made up of 28 villages, the inhabitants of this Subdivision are the Mbororo, reputed to be the large breeders who have gradually settled down. Next to them are the Gbaya and the Mboum. These ethnic groups are gradually joined by the Laka, the Foulbe, the Choa Arabs, the Kotoko, and the Karé who are disseminated in very small numbers in the population. Islam and Christianity are the two religions practiced by the

\footnotetext{
2 This village was known thanks to the priest of the Catholic mission Henri Bocquéne who wrote a paper entitled: moi, un Mbororo. In fact, to do research on the Mbororo, he had a road created through the village of Yafounou. Traders have started to use the Ngaoui cross-border market.
} 
people.

One of the historical features of the Mbororo which calls for attention in the context of this study is the place which this ethnic group has succeeded to occupy till date despite the effects of modernization (Burnham, 1996: chap. 5; Bocquéné, 1986). While they have maintained their traditional way of life marked by pastoralism, nomadism, prolonged stays in the bush, reluctance towards Western schools, and the other sedentary populations have undergone an evolution. In popular imagination, they are seen as "uncivilized" or "backward" populations compared to the sedentary populations who, under independence, had earlier opted for a modern way of life. Nevertheless, in the quest for their emancipation, the United Nations Working Group on Indigenous Populations and international financial institutions like the World Bank have officially recognized and identified these nomadic Mbororo pastoralists alongside the 'Pygmies' who are hunter-gatherers as "indigenous peoples" (the report of the working group of experts of the African Commission on Human and Peoples' Rights, on indigenous populations and communities, p.102). From then on, a UN dynamic was thus set up on the indigenous issue. The above arguments require that we first agree on the understanding of the object of study.

To understand the concept of indigenous people, we will rely on the definition expressed in the World Bank Operational Manual according to which:

The expressions "indigenous peoples" (...) describe social groups with a social and cultural identity which is different from that of the dominant groups in society and which makes them vulnerable in the development process. Many of such groups have a status that limits their ability to defend their interests and rights to land and other productive resources, or that limits their ability to participate in and benefit from development (Group report Expert Working Group of the African Commission on Human and Peoples' Rights on Indigenous Populations / Indigenous Communities, 2005, p.105).

This definition identifies three (3) essential elements for a good understanding of this notion: cultural singularity, the situation of non-dominance and marginalization from an economic, political and socio-cultural point of view, but not necessarily numerically like the observes Schulte-Tenckhoff (Pierrée-Caps, 2008, p.1028 cited by Mouangue Kobila, 2009, p.37). Contrary to the notions of minorities which favour numerical weakness or of "indigenous populations" which are legitimized by the first-time settlement on a territory and the exclusive rights on ancestral land (Mouiche, 2013, p.289; Ngando Sandje, 2013/3, p.24), that of "indigenous people" further integrates socio-cultural specificities. What is at stake here is the notion of legal personality, which the people have in international law and which gives access to the rule of law (Bellier, 2013, p.25). It is within this general framework that the notion of "indigenous people" should be understood.

As for sedentarization, it is defined here as:

The evolution of the practices and lifestyles of nomads who move from permanent mobility (nomadism) with the whole family and livestock to their 
settlement in a territory where they build houses, combine livestock and seasonal agricultural activities, send their children to school and diversify their activities (commerce, etc.) (Nathalie Kossoumna Libaa, 2008: p.31).

In other words, sedentarization participates in the fixing of a sociological entity on a territory which allows the enjoyment of socio-educational infrastructures. It is important to make mention of the fact that the Cameroonian State considers sedentarization as a central variable in the process of identifying "groups of marginal populations", given the imperative of control and the affirmation of State authority over the populations of its territory, notably through the establishment of legal ties of nationality and the levying of taxes (Donfack Sonkeng, 2001/2002, p.113).

These definitions being given: what determines the unique socio-political trajectory of the Mbororo in Ngaoui Subdivision (Cameroon)? As responds to this question, we argue that the Mbororo of this district have a singular socio-political trajectory which contrasts with the definitional and identifying elements enshrined in the international and Cameroonian conceptions which would make them indigenous and marginal peoples. This socio-political trajectory follows the objective criteria for assessing sedentarization and local domination.

From a theoretical point of view, this study is based on the coloniality of power (Grosfoguel, 2004, pp. 315-306; Schuft Laura, 2010, p.87; Quijano, 2007, pp. 111-118), to study the contemporary socio-political status of the Mbororo of Ngaoui as recompositions of power relations of the colonial type, between power holders and the dominated. The data was collected through documentary research, series of interviews (semi-structured and semi-participatory) conducted with six categories of actors: breeders, farmers, administrative authorities, political authorities, traditional authorities and ordinary citizens. The surveys were carried out from May 1 to May 30, 2019 in two Subdivision capitals: Djohong and Ngaoui. The choice of these localities is motivated by the fact that the Mbororo and their herds are highly concentrated in the said localities and they have established their sedentary habitats there. The analysis of the data collected gave rise to two types of concerns. The first presents the Mbororo as a sedentary sociological entity (2). The second articulation sees them as a dominant sociological entity (3) in the district of Ngaoui.

\section{The Mbororos: A Sociological Entity Settled in Ngaoui Sub-Division}

Following political, economic, social and cultural changes of the twentieth century, the sedentarization of nomadic societies appear to be a universal phenomenon (Sandron, 1998 cited by Kossoumna Libaa, 2008). However, there are different forms of sedentarization which take place following different rhythms from one country to another or from one locality to another. According to information gathered on the field, the dynamics of sedentarization of the Mbororo in the locality of Ngaoui began around the years 1975 and 19 86. It is important to mention the fact that these dates correspond to the development of the cross-border cattle market of Ngaoui and to the establishment of administrative services in the said locality (Djida Danga, 1998-1999, p.21-25). To identify the dynamics of sedentarization of the Mbororo in Ngaoui, it is important to study these factors (2.1) on the one hand, and the modalities of these sedantarization on the other hand (2.2). 


\subsection{Factors of Sedentarization of the Mbororo}

The better explanation of a factor holds "to appeal to a strong determinant of social change. A factor is in fact an element of a given situation which, by the sole fact of its existence or by the action it exerts, causes or produces a change "(Rocher, 1968, p.25). The explanatory factors for the sedentarization of the Mbororo in Ngaoui are twofold: on the one hand, friction with the Foulbe (2.1.1), on the other hand, cross-border crime (2.1.2).

\subsubsection{Historical Friction with the Fulanies}

Nomadic pastoralists have always been and are still a subject of prejudice till date. Besides the suspicion of superficial Islamization in view of their perpetual displacement or their sensitivity to the evangelization by the Evangelical Lutheran Church of Cameroon (EELC) as we will see, it is important to raise the historical grievance that has degraded the pastures. These prejudices have fuelled the rivalries for the appropriation of pastures (habre geene) between the Foulbe and the Mbororo. In fact, the former blames the latter for taking too long to water their animals. As a result, the Foulbe prohibited the Mbororo from using the farms at the same time with them, to prevent their animals from meeting each other. Likewise, the Foulbe of Tibati were hostile to Mbororo's presence. Three periods follow one another in these tensed relations that the Mbororo have maintained with the Foulbé, including a coexistence between the two, the capture of a pastoral rent (1900-1930), the restraint of the Mbororo on the outskirts of the lamidate (1930-1960), the complete expulsion and repeated chase (Dognin, 1981, pp. 139-157). In 1899-1900, Tibati placed the Djafoun in Lompta, at the foot of Tchabbal Mbabo. The place is again relevant from a pastoral point of view, as it is close to the natronous source of Galim, called Bouré by the Mbororo. It will be the only large natronée source on the plateau which the Mbororo will have exclusively (Jean Boutrais, 1994: pp.175-196). The Mbororo of the plateau therefore had to face two historical constraints: the need to have a notorious source and the need to benefit from protection. Thus, the 1920s and 1930s were marked by a dispersion of the Djafoun, either towards Bamenda or towards the east of Adamaoua Region ; Ngaoundéré and especially Meiganga in the of Mbéré Division. This is the place to note that the tensions between the Mbororo herders and the Foulbé aggravated by an epizootic of rinderpest virus which raged in Ngaoundéré from 1927 to 1928, causing 20,000 losses, according to an administrative estimate. However, for the Foulbé, the disease was introduced by the Mbororo who came to settle on the eastern plateau and then entered the lamidat. To the east, the Mbororo Djafoun and Woodabe got stationed on the part of the plateau that falls under the lamidate of Rey. To prevent them from entering Ngaoundéré, the Foulbé and French breeders occupied the land through the installation of the Pastoral field in Goundjel in 1928 and the creation of the Bélel village by the Foulbé in 1936 (Taguem Fah, 2014: p.59-60). The lamido of Ngaoundéré confined Mbororo pastoralists at the border of Rey in Djilougou in 1941 to prevent Mbororo from entering. In the south, the Mbororo Djafoun are also removed from the surroundings of Dibi and contained on the outskirts of the lamidat, more precisely around Martap, the slopes of the Djerem basin, the Mbéré plain. The Djafoun are thus numerous in Kognoli, Ndaskoul, Mangom and Makor. Wodabe come from Tignère stationed near Martap, in Makane and Mandjala. Wealthy Foulbé from Béka, near Ngaoundéré, thus expelled Djafoun from Mangom in the 1930s. In 1957, 
Wodabe Yayanko'en were evicted from the pastures of Galdi, south of Dibi. In 1978, the Akous were expelled by agents of the livestock service from the vicinity of Kognoli and they returned to the territory of Tibati. Years after, their numerous attempts of infiltration have shifted them around Martap each time, the livestock service intervened vigorously to push back the Mbororo.

An objective look of the above reveals that the sedentarization of the Mbororo in Ngaoui is a source of friction with the Foulbé. Faced with the hostility of the Foulbé people's in the localities of Ngaoundéré, Banyo or Tibati, friction with the agricultural populations, the Mbororo opted for the modification of their farming practices. To do this, three livestock systems coexist in the locality. These practices includ the sedentary livestock system, the semi-sedentary livestock system and the transhumant livestock system (Natalie Kossoumna Libaa, 2008). In addition to friction with the Foulbe, cross-border crime is another determining factor in the sedentarization of the Mbororo in Ngaoui.

\subsubsection{Cross-border Crime}

Cross-border crime is historically manifested by "ambush processes on the road which generally characterizes their operation mode" and the phenomenon of " highway robbery", arm robbers (Saïbou, 2004). Cameroon's Mbororo breeders presents a mixed picture in that they are active members of this criminality and are also the main victims (Christian Seignobos, 2011). This duality on their relationship to organized crime has its roots in a long history of marginality rooted in their way of life, the impact of ecological crises on their socio-cultural system and the exploitation of which they are object (Saibou, 2006). In Cameroon too, hostage-taking to the detriment of the Mbororo has become daily activity, especially in the areas of Ngaoui and Djohong close to the Central African Republic border and between Bibémi and Léré on either side of the Chad-Cameroon border. The military sources already indicated it clearly for the year 2004: "These hostage-takings exclusively carried out on the Mbororo ethnic group, are made possible because of the lack of collaboration with those who live in autarcy in their fearing camps and this has as effect, the repeated arm rubbery attacks. This situation is further complicated by the fact that some hostages are kidnapped and taken to a foreign territory, which does not allow the elements of the 3rd BIR to act effectively "(Ibid). This situation had important implications for the Mbororo. It forced this Fulani category to change their manner of living. Letting aside a way of life practiced for centuries like coming in contact with bank structures. Indeed:

When it became increasingly difficult and risky to drag herds over long distances, the ambush targeted at the edges of cattle markets replaced the raids. The breeders were spun and expected at the time of return; the bandits knew how much money they made from the sale of their animals. Gradually, the Fulani herders, and in particular the Mbororo, learned to trust banks, hence the establishment of savings and credit cooperatives near the markets. The ranchers learned to negotiate and sell their cattle in return for a proof of sale, a check for the money to be collected in town. Sometimes, the market was no more than a stock exchange where the breeder came to exhibit the characteristics of his 
animals, make an appointment with potential buyers who will examine the goods in a safe place and conclude the sale there (Saibou, 2006: p. 30).

In addition to membership in bank structures, cross-border crime has forced the Mbororo to settle in urban centers. Rougayatou Moussa, the wife of an agro-pastoralist reported by, gave up the bush to live in the city to protect her family against cross-border insecurity in these terms: "The phenomenon of cross-border crime is a danger for my children. In addition, with my income from sewing, I manage to feed my children and send them to school "(Interview of 05/06/2019 in Djohong). The climate of insecurity has forced Mbororo to settle in the cities in several ways. First the men buy or rent compounds, settle the women and children there with the prospect of joining them later. Others, under threat of kidnapping, leave the bushes to settle permanently with their families in the city. Still others prefer to live in the bush and visit their family at weekends thereby making transhumance impossible ; bandits have achieved what public authorities have not been able to achieve through the promotion of ranching $^{3}$, namely to force the Mbororo to settle down. Fix homes or the construction of mud brick huts is another indicator of the sedentarization of the Mbororo. This change in lifestyle and accomodation has long been presented as the condition for all material and social progress for indigenous peoples (Mouiche, 2011). The Mbororo have opted for several decades to settle their habitat and their activities. The habitat, formerly made up of traditional huts using ancient architecture, is gradually being modeled on the architectural model of Christian buildings (bricks, concrete blocks, zinc roofs, windows, etc.) (Hamadou, 2014, p.82-83). This fixation on the territory not only makes it possible to acquire land and political rights, but also to integrate the socio-economic life of this locality and to have a more pleasant living environment: boreholes, wells, schools in within the village, nearby health centres.

Several corroborating sources attest that some herders have also started to buy land and houses that they rent out in the villages of Djohong, Ngaoui, Meiganga, Ngaoundéré etc. this ethnic group suffers poverty which is caused by the frequent herds losses. Essentially, the Mbororo distinguish between two forms of sedentarization: simple settlement (gasugo) and building-(nyibugo). But this is the second initiative that tends to become widespread. It is therefore appropriate to study the modalities of sedentarization of the Mbororo.

\subsection{The Modalities of Sedentarization of the Mbororo}

In addition to affiliation to bank structures, the establishment of housing and the sedentarization of the Mbororo in Ngaoui takes place in two major ways. On one hand, the diversification of economic activities (2.21), on the other hand, the relative conversion to Christianity and access to health and educational infrastructure (2.2.2).

\footnotetext{
${ }^{3}$ It is a form of animal husbandry that was promoted by the Cameroonian state at the instigation of the World Bank in the early 1980s in the Adamaoua Highlands (Cameroon). It consisted of the granting of credits for the construction of fences and the purchase of livestock intended to permanently occupy a pasture allocated "free" by the public authorities. For more information on this project, which ended in failure, usefully read Albert Douffissa, 1993: p.143).
} 


\subsubsection{The Diversification of Economic Activities}

The diversification of economic activities is an important variable for studying the modalities of sedentarization of the Mbororo in the Ngaoui Subdivision. It operates through engagement in agriculture and openness to trade.

With regard to agricultural engagement, the comparison of data collected on the field from Mbororo pastoralists indicates that when they arrived Ngaoui, they did not know how to cultivate (Generally, Nomads do not know how to cultivate) and had only "contempt for the handlers of the hoe" (Hurault, 1964, p 22-71). In the Fulfulde language, there are still expressions that reflect the historical denigration of agricultural practices: "nguessa do wartan tollore na'i am"; "Ngessa do wartan na'i" (this field will become the pasture of my oxen). As for the children, they grow up familiar with the cattle that they get to know from an early age. They acquire what the Mbororo call "'dabare amin" meaning pastoral civilization. But their permanent settlement in a single area, has rendered cattle rearing and livestock insufficient in providing food and be able to meet all needs. Agriculture has therefore imposed itself on the Mbororo populations for reasons of subsistence- Field observations reveal that the practice of agro-pastoralism which is, understood as the orientation towards a system of mixed activity or production has been adopted by the mbororo after their coming in contact with agricultural populations. "Riskou dje timata, dje fewata" (wealth which does not end and which does not betray either); "Yamnougo Yonki" (feeding souls); "Oustougou Wahalla wonnougo Sede" (reduce expenses); "To a remataa, a harataa" (If you do not cultivate, you will not eat to your satisfaction). These expressions gathered from breeders reveal the importance of agriculture to the Mbororos place on agriculture. According to these breeders, several factors have contributed to the opening of the Mbororos to agriculture. These factors include:

Cultural exchanges with the agricultural populations, cattle diseases which led to (serious losses in livestock), needs, recourse to agriculture to revive pastoral activity. Commitment to agriculture is also a response to change in diets and a decline in the value of livestock relative to food productions. Moreover, adoption of agricultural activities do not only reduce food expenditure, but also compensate the loss of the financial power caused by kidnapping of breeders ; and to benefit from financial support granted by the State or by NGOs to farmers (Interview of 05/06/2019 in Djohong).

The agricultural engagement of the Mbororo involves a real learning of new activities, their schedule and in their techniques. To do this, the Mbororo first hire farm workers and then go to work themselves. We met several breeders who cultivate large fields of corn or cassava. Four (4) striking examples are those of Alhadji Amadou Bado, Alhadji Idrissou, Alhadji Garba and Alhadji Gagare of Djohong who know the great value of manure. They park their animals on areas prepared for the next season's of corn crops. Albert Doufissa already underlined in 1993 that $41 \%$ of Mbororo breeders were already engaged in the agricultural activity. These were small crops of tubers or vegetables. Thanks to animal manure, sedentarization is accompanied by the development in small areas close to homes of 
continuous and intensive cultivation of corn. The majority of settled herders thus guarantee food security for their families. It is therefore important to note that the agriculture practiced by the Mbororo is no longer limited to the "waldee" or to small areas around the "saare" (compounds). The Mbororo are increasingly organized into cooperatives. They benefit from financial support provided by international organizations such as the World Food Program (WFP), Première Urgence Internationale, Lutheran World Federation. The crops are made up of beetroot, tomato, amaranth, black nightshade, red guinea sorrel, green guinea sorrel, chili, cabbage, salad, carrot, cucumber, okra, Pepper and beans). The diversification of economic activities also takes place under the openness of the Mbororo to commercial activities.

Before the involvement of the Mbororo to commercial activities, it is important to point out that this activity was the historical prerogative of the Bornu, Haoussa and Foulbe ${ }^{4}$. But, today the Mbororo practice it widely and are more involved thus oxen merchants (palke'en) now include the Mbororo in their ranks. They are also owners of herds in the bushes (nai'i mari: and the number of their cows has increased in size thanks to the profits they have obtained from commercial activities, collected in the field. There are several categories of Palke ${ }^{5}$ : Palke from Ngaoui and the surrounding villages who buy oxen at cheaper prizes in village markets site in order to resell in urban centers. The different pelke includ Palke who go to buy the oxen in the Central African Republic (CAR), for the resell in Ngaoui; palkes who come from neighbouring villages and towns to buy oxen in Ngaoui to resell them in Kourmi, that is to say in the Central and South regions of Cameroon. Female engagement in trading dairy products also complete pastoral specialization. However, this female involvement in the dairy products trade is not systematic. More common among the Akou than among the Djafoun, it is typical of the lineages who recently arrived on the plateau (Boutrais, 1999, p.153). In addition to the diversification of economic activities, the sedentarization of the Mbororo is also taking place through a relative openness to Christianity and its corollary, access to development.

2.2.2 The Relative Openness of the Mbororo to Christianity and Access to Health and Educational Infrastructure

The relative conversion of the Mbororo to Christianity and their access to health and educational infrastructures is also an important modality of sedentarization. This conversion is part of the decision to evangelize this Fulani fraction manifested by the Norwegian missionaries (Lode Kare, 1990; p.10). The strategic objective was not only to get the Mbororo out of the spiritual ghetto in which they find themselves, but also to block the way for the expansion of Islam towards the south of Cameroon (Bonne Mbang Sodéa, Owona Ndounda, 2019, p .42). In fact, before 1958, the decision to evangelize this people had already been introduced in Adamaoua for three (3) decades. In the field of evangelization and in a subtle way, the missionaries established contacts with the Mbororo in the towns of Meiganga, Fada and Djohong, present day Mbéré Mbere division. The missionary campaigns of the Evangelical Lutheran Church of Cameroon (EELC) to the Mbororo in the Adamaoua

\footnotetext{
${ }^{4}$ This was already the case in the early 1950s, when Ngaoundéré was the only forail (Froelich, 1954: 23 cited by Jean Boutrais, 1994, p.191.

${ }^{5}$ Palke means beef sellers in local language.
} 
Region lasted nearly half a century. Within the framework of the religious enterprise of the Evangelical Lutheran Church of Cameroon (E.E.L.C.) towards the Mbororo, the promotion of educational and health infrastructure was a policy of charm that the missionaries used and still use today to evangelize the Mbororo. It was through medical care that they evangelized them. During these medical consultations, nurses who happened to be missionaries took the opportunity to share the gospel with them. This form of evangelization took place until the 1990s. It began in the hospitals of Meiganga and Ngaoundéré during the 1960s. Likewise, during the evangelization campaigns among the Mbororo, the missionaries were accompanied by nurses. In addition, in each Lutherian hospital, before the start of the morning service, a prayer is said, accompanied by a sermon. These actions were used for the conversion of the Mbororo to Christianity.

The promotion of educational infrastructure is also another tool of seduction used by missionaries in the dynamic of converting the Mbororo to Christianity. These missionaries believed that they could easily evangelize the Mbororo through education. The first schools were built in Meiganga and Djohong. Their creation goes back to the early 1960s (Kare, 1990: 205). Besides the contribution of the Evangelical Lutheran Church of Cameroon (EELC), the State and international organizations have also played an important role in the educational domain. In this perspective, the Danish Refugee Council (the Danish Refugee Council), the Lutherian World Federation (the Lutherian World Federation) promote schooling in the Mbororo community. Two health centers were established respectively in the localities of Ngaoui and Garga Pella. According to Eddy Sangang Gustave, a consultant nurse in Borgop ${ }^{6}$, the Wollarbe clan remains the most open to health infrastructure, with a $90 \%$ attendance rate in health centers (Interview of 05/06/2019 in Djohong). Therefore, women responsible for children, remained very present in health centers for vaccination campaigns and boldly refused to go on transhumance with their husbands. These women were conscious of the importance of this health infrastructures for them and their children. As a result, most Mbororo women preferred to live in the cities in order to be close to schools and hospitals. As illustration, Halima Adamou, Ibrahima Hamadou's first wife (an agro-pastoralist) prefers to live in the city for school and health reasons: "milking is painful and not very profitable. In addition, the city allows me to be close to my children who go to school and health centres " (Ibid). The sedentarization of the Mbororo also accentuates their Islamization which, while being affirmed by those concerned, often remained superficial. Once learning the Quran is completed and sanctioned by the "doa" prayer ceremony, it is difficult to return to herding the cattle. Koranic education competes with pastoral knowledge and often prepares a rural exodus of young people (Boutrais, 1999: p.156). During surveys, we observed that the young Mbororos living in urban areas lack interest in cattle rearing. They learn motorcycle driving, taxi driving"jobs" and they are in all the gold mining yards in Lom. For their sedentarization, the Evangelical Lutherian Church of Cameroon (EELC) offers to young Mbororo converted to Christianity paid jobs to help them support themselves. This is the case of Hareiratou Maraima who has worked since 2002 in one of the Departments of Evangelization of this Church in the city of Ngaoundéré. Daoudou Jaa'e, a computer science graduate, is also

\footnotetext{
${ }^{6}$ It is a village located $19 \mathrm{~km}$ from Djohong.
} 
employed at Sawtu Linjiila radio. Pastor Abdoulaye was recruited for the Islamic-Christian Relations service in Ngaoubela (Bonne Mbang Sodéa, 2005, p.75). All the testimonies agree to note the contribution of the Christian religion in the dynamics of sedentarization of the Mbororo. From another angle, sedentarization enshrines the Mbororo as a dominant sociological entity.

\section{The Mbororo as a Dominant Sociological Entity in Ngaoui Subdivision}

In the first part of this work, we explored the factors and modalities of sedentarization of the Mbororo in Ngaoui, we now propose to put their local domination in context. Before studying the determinants (3.1), it is important to highlight the manifestations (3.2).

\subsection{The Manifestations of the Domination of the Mbororo}

The domination of the Mbororo in the locality of Ngaoui is manifested by their relative possession of traditional power (3.1.1) and their central position in local political power (3.1.2).

\subsubsection{The Relative Possession of Traditional Power}

In terms of the structuring of traditional power, Mbororo society has not known throughout history a sufficiently solid socio-political organization compared to the other sedentary Fulani fractions (the Foulbé), because they are too dynamic and in perpetual displacement. It is only with the dynamic of sedentarization that the Mbororo have established stable modes of political organization in Ngaoui. They are organized around a community leader called "Ardo" and in a plurality of pastoral villages. The village "wuro) is the smallest traditional administrative unit commanded by Ardo, the equivalent of the village chief. The Mbororo hold traditional power in the capital town of Ngaoui through the canal of their ardo. Out of a total number of seventeen (17) 3rd degree chiefdoms listed in this part of the Region, the ethnic distribution is as follows: the Mbororo (7), the Gbaya (06), the Fulany (04) and the Mboum-Mbéré (01). It is important to note that traditional chiefdoms continue to exert a strong influence on the course of political, economic, social and local life in Cameroon (Alawadi, 2017: 355-376). The locality of Ngaoui was officially founded by the Mbororo. According to Raphael Ndanga:

After nine (9) years of reign, the Chief Bouba goes on pilgrimage to Mecca. Adamou Nyaka, his brother, is acting during his absence and is illustrated by the [acts of abuse of power] which will force a large section of his subjects into exile. Upon his return after a two-year absence, the Chief Bouba refuses to resume traditional power. Adamou Nyaka therefore entrusted power to the youngest prince Mohammadou Labi in the 1950s. The arrival of Ardo Mohammadou Labi to the throne prompted the return of subjects who had fled under the reign of Adamou Nyaka. Rumors of festivities that are organized every Friday lead to an influx of new residents who settle in Ngaoui by building residential houses (Djida Ndanga, 1998/1999: p.37). 
The above argument makes it possible to affirm the grip of the Mbororos over the Ngaoui Subdivision. Mohammadou Labi made political use of the festivities. These festivities were used to build relationships and gain the allegiance of local people. From then on, the first districts of the locality were formed. These are the districts of Lamorde, Fadisonka and Camp Kare. An evocation of this turbulent history between the Bamoun royalty and the Mbororo of Noun largely accounts for these asymmetrical relationships.

However, in terms of inter-lamidal relations, the Chief of Ngaoui maintains relations of suzerainty and patronage with the "indigenous" Gbaya chiefdoms. The ardo of Ngaoui has as superior authority the traditional chief of the 2nd degree of Ngaoui. He has the power to induct the 3rd degree traditional chiefs of this locality. Just of recent, the second ardo of Ngaoui was inducted by Yaya Doumba Marius, the indigenous Gbaya chief of Djohong on May 29, 2019. According to Gilbert Djidéré, Secretary of administration of Ngaoui (Interview of 05/07/2019 in Ngaoui), three indigenous chiefdoms (03) exercise their authority over the traditional power of Ngaoui. Much of this district of Ngaoui is under the authority of the 2nd degree chiefdom of Djohong. These are the chiefdoms of the villages of, Ngaoui, Diel, Garga Pela, Djabori, Tourake, Bawaka-koe, Bawako Oumarou, wanda-Ndere and many others. The first-degree chiefdom of Meiganga exercises its power over the traditional chiefdom of Bafuk; while the traditional chief of the 2nd degree of Lokoti covers part of this sub-division, in particular Alahmdou, Bodjo. This relationship of suzerainty could also be explained by historical agreements. According to field surveys:

the Ngaoui cattle market is the result of a historic agreement between four traditional chiefdoms namely: Djohong, Mboula, Meiganga and Lokoti. Under the terms of this agreement, there was talk of each lamido granting a site to house the border cattle market. This site was to be administered by an Ardo (representative of a group) named Wahabi, related to Ardo of Djalingo, father of Ardo Bakary Bem de Meiganga. This border market was to guarantee the supply of meat to the Gbaya, a mixed economy people, living from hunting, fishing and gathering, while practicing subsistence agriculture ${ }^{7}$

However, this relationship of suzerainty and patronage between the ardo de Ngaoui and the "indigenous" Gbaya chiefdoms are increasingly questioned. In fact, the claims for the reclassification of the 3rd degree chiefdom of Ngaoui to 2nd degree by the Mbororo in the democratic movement are certainly one of the most obvious illustrations of the scope of "social renegotiations" (Leservoisier, 2009: 24- 43) in progress in Ngaoui. By the request of July 17, 2016, signed by 23 traditional chiefs, and addressed to the Minister of Territorial Administration and Decentralization, the Mbororo are calling for the reclassification of the 3rd degree chiefdom of Ngaoui to 2nd degree. The political stakes of the reclassification of the traditional chiefdom of Ngaoui are of several types: first, this reclassification aims to establish the autonomy of the chiefdom of the Mbororo community of Ngaoui vis-à-vis the tutelage of the indigenous Gbaya chiefdoms and therefore the full jurisdiction of Ardo over

\footnotetext{
${ }^{7}$ Bem in the first sense means in Fulfulde " son'. But in the context of interethnic relations in the Mbéré department, it refers to a secular term attributed by the Gbaya to the Mbororo which reflects historical links (Interview of 05/07/2019 in Ngaoui).
} 
the entire territorial area of this district. Then, it aims to increase the possibility of Ardo of Ngaoui not only to obtain an audience with the Head of State, because in practice, only traditional chiefs of the 1st and 2nd degree are entitled to hearings granted by the head of state during regional tours but above all, to increase the possibility of eligibility for the electoral college of senators. These demands arise in a political context where decentralization will contribute to the revalorization of the traditional chiefdom by taking into account chiefdoms in the transferred competences and their representation within the Senate and regional councils. Also, future regional councils will be partly composed of representatives of the traditional command elected by their fathers. This claim therefore opens up any possibility of eligibility of the Mbororo to the electoral college of senators (Assana, 2014: 29). Finally, these claims are underpinned by financial issues. From now on, all the traditional chiefs receive a monthly allowance calculated on the basis of the numerical size of their population as well as an allowance for special charges" and the statute of their traditional chiefdom whose amount is fixed at 200,000 FCFA for 1st degree chefs, 100,000 FCFA for 2nd degree chiefs and 50,000 FCFA for 3rd degree chiefs (Cf article 22 of decree $n{ }^{\circ} 2013 / 332$ of 13 September 2013 amending and supplementing certain provisions of decree no. ${ }^{\circ} 77 / 245$ of July 15,1977 , on the organization of traditional chiefdoms). Anything that exacerbates greed and could explain the renewed interest in the claims for the reclassification of traditional Ngaoui chiefdoms to 2nd degree. Through this reclassification, their position will be further strengthened in traditional power. A Mbororo informant boldly states:

Unlike the Gbaya ethnic groups which have several cantons and their 1st and 2nd degree chiefdoms, the Mbororo chiefdoms are deliberately maintained in 3rd degree status by the government. Mbororo peoples therefore feel that they are under the tutelage of the leaders of other ethnic groups and clans. We would like to have our autonomous canton, having Ngaoui as its capital, and made up of chiefdoms from the pastoral villages of Diel, Garga Pela, Djabori, Tourake, Bawaka-koe, Bawako Oumarou, wanda-Ndere, faada etc. (Interview on 05/06/2019 in Ngaoui).

Such a demand is a testament to the changes underway, in particular the democratic effects on political imaginations, as it was inconceivable, even a few years ago, for the Mbororo to take this type of action. In other words, the Mbororo seek to endow themselves with a chiefdom in the same way as the indigenous Gbaya chiefdoms with the hope that it will help to make their voices heard well and to renegotiate their relations with them on an equal position with other traditional leaders. But these claims for the reclassification of the Mbororo chiefdom of Ngaoui to 2nd degree do not seem to have received a favourable response from administrative authorities. The Ministry of Territorial Administration and Decentralization (MINADT) reacted with the correspondence of December 22, 2016, opposing them with suspension measures ${ }^{8}$. Besides the relative control of traditional power, the domination of the

\footnotetext{
8 The 1995 measure "suspension, creation, reclassification and rehabilitation of traditional chiefdoms has been in progress since 1995 (cited by circular letter No. 0215C / LC / MINAT of September 13, 2000. However, the Minister of Administration of the territory, Paul Atanga Nji, recently signed a circular letter setting out the modalities for the creation, reclassification and rehabilitation of traditional chiefdoms. The main lesson is that
} 
Mbororo is also noticeable through their central position in local politics.

\subsubsection{The Central Position of the Mbororo in Local Politics}

To understand the local political dynamic, it is necessary, according to William Genieys et al (2000: 103-119) to analyze the articulation of the relationships between political leadership and the territory. This amounts to asking how, Mbororo acquire and maintain their electoral and political legitimacy on the one hand, and how once brought to power, the latter organize their relations with other ethnic groups in order to imprint their Mark on the other hand. The central position of the Mbororo in local politics can be seen in the Ngaoui, where they provide political leadership in the commune of this locality and the chairmanship of the CPDM section. The influence of this Fulani fraction over the municipal executive is achieved through the channel of a Mbororo Mayor Abdouramou Labi, who has been in charge of this council since 2002, as shown in this table.

\begin{tabular}{|l|l|l|l|}
\hline $\begin{array}{c}\text { Names and surnames of } \\
\text { principal Mayor }\end{array}$ & Mandate Period & Ethnic Group & Religious Belonging \\
\hline Adoulaye Beiladji & $1996 / 2002$ & Fulbe & Muslim \\
\hline Abdouramou Labi & $2002 / 2007$ & Mbororo & Muslim \\
\hline Abdouramou Labi & $2007 / 2013$ & Mbororo & Muslim \\
\hline Abdouramou Labi & $2013 / 2018$ & Mbororo & Muslim \\
\hline Abdouramou Labi & $2020 / 2025$ & Mbororo & Muslim \\
\hline
\end{tabular}

The Rural Council of Ngaoui was created in 1996. Before that date, the locality of Ngaoui depended on Djohong. The Mbororo were represented by 06 municipal councilors in that council. But, since the creation of the council of Ngaoui, the Mbororo have succeeded in securing control of the municipal executive of Ngaoui by retaining the function of mayor since 2002. The only exception comes from the very first term (1996 to 2002).) where, the Foulbe ensured the direction of the municipal executive of this commune during a mandate by the channel of Abdoulaye Beiladji. The council of Ngaoui is made up of 25 municipal councillors. To achieve such a feat, the Mbororo had to win a sufficient majority of 13 out of 25 councillors to elect the municipal executive, with or without consensus, with or without the will of other ethnic constituents. For the Fulbe ethnic group, the post of First Deputy Mayor is reserved; in Gbaya, the seat of the second Deputy Mayor. In addition to controlling the municipal executive of Ngaoui commune, the Mbororo also lead the presidency of the CPDM Section of Ngaoui. This section was created after the break-up in 2008 of the Main Section of the Subdivision of Mbéré-East (Djohong). In local CPDM structures of Ngaoui, the Mayor (mbororo), Abdourame Labi, was elected in 2002 as president of the RDPC Section of Ngaoui, against the Foulbé candidate, Beladji Abdoulaye. Abdourame Labi was renewed in 2007, 2012, and 2020. For the Foulbé and Gbaya groups, the presidencies of the Youth branch of CPDM section since 2002 (Aboubakar Abbo) and of the OFRDPC section

the creation of chiefdoms is now subject to "express authorization" of the Minister. It is no longer only the act of civil administrators (Sub-prefects, Prefects, Governors) in the field. A consequence no doubt, of the anarchy often criticized in this area, in particular, through inappropriate creations, generally in the margins of the texts required in the matter and the multiple challenges at the head of the traditional chiefdoms. Read on this point, the circular letter $\mathrm{N}^{\circ} 00000831$ / LC / MINAT / SG / Dot dated May 11, 2018. 
(Adama Delphine) are respectively reserved. As can be seen, local political life is dominated by the Mbororo despite their low level of education. The correlation between educational attainment of political participation cannot be established systematically.

For ethnico-religious considerations, the Mbororo first identified with the National Union for Democracy and Progress (UNDP), the political party of Peul Bouba Bello Maigari, under the diligence of the very first Mayor of the council of Ngaoui, Abdoulaye Beiladji, appointed by the political party named National Union for Democracy and Progress (NUDP) (1996/2002). The latter led the list of this party in the locality of Ngaoui and, the Mbororo voted overwhelmingly for this party, before reconverting into the ranks of the Cameroun People's Democratic Mouvement (CPDM) in the years 2002, following the 'investiture of Abdouramou Labi (prince of Ngaoui) as candidate of the Cameroonian People's Democratic Movement (CPDM) in the municipal elections as the mayor of Ngaoui 2002. In the local popular imagination, the National Union for Democracy and Progress (NUDP) was seen as the political party of Muslims, while the CPDM was projected to be the party of "Christians" and "unbelievers". Likewise, in a political context where development of certain localities in the Littoral region were delayed due to their adherence to the opposition (Socpa, 2000, pp. 91-108), the Mbororo populations quickly understood the advantage they can derive from affiliating in the CPDM, the ruling political party. The political links with the central power offer the best guarantee to defend their local interests: the protection of land rights, the reclassification of the statutes of their chiefdoms, the capture of development rent, etc. (Interview of 05/07/2019 in Djohong). To do so, they invested basic units and local governing bodies of this political party, in order to make visible to the central power a certain number of complaints in terms of access to basic health infrastructure, education, but above all to preserve their local political leadership. Likewise, the appointment of Hamadou Lamou, as Head of Center of the regional branch of the National Social Insurance Fund (CNPS) of the Adamaoua region (2010/2013) and that of the North (since 2013) and, as President of the Ngaoui Council Commission and Hamadou Abbo, as a member of the Ngaoui Council Commission of the said administrative district, reinforced their reconversion in the CPDM. According to an informant, the shift of the Mbororo into the CPDM can also be explained:

through political lobbying by Mayor Abdouramou Labi on the Mbororo community. Being a trained veterinarian, he has a strong hold on the Mbororo breeders. In this way, his election as candidate of the Cameroon's People Democratic Mouvment (CPDM) in the Ngaoui Council in 2002 against the candidate Abdoulaye Beiladji who distinguished himself throughout his mandate (1996/2002) by an attitude of his political arrogance and the conflict of political leadership with the Chief of Ngaoui, have strengthened the Mbororo in their reconversion into this political party (Interview of 05/06/2019 in Djohong).

To better understand the local political domination of the Mbororo in the Ngaoui district, it is important to study its determinants.

\subsection{The Determinants of the Domination of the Mbororo}

The local political domination of the Mbororo in the locality of Ngaoui is due to the 
conjunction of three resources: their favourable demographic framework, their economic weight (3.2.1) and the new national and international legal context favourable to indigenous peoples (3.2.2).

\subsubsection{The Favourable Demographic Framework and Economic Weight}

The main determinant of the political domination of the Mbororo in Ngaoui subdivision is their favourable demographic and economic weight. This Fulani fraction is a social group with strong demographic potential. Indeed, the numerical data on the ethnic composition of the population of this area from its origins till date, the demographic evolution of the Mbororo and their migration in to this locality is sorely lacking in the available literature. Demographic statistics are imprecise. Nevertheless, cross-checks of administrative data make it possible to fill this gap. According to the census carried out in 2016 the total population of Ngaoui has been estimated at 40,000 inhabitants and the percentage according to every ethnic groups goes as follows: the Mbororo (50\%), the Gbaya (40\%), the Foulbés (5\%), Mboum-Mbéré (3\%), Arab-Choa, Hausa, Kanouri or Bornouan, Toupouri, Kotoko, Laka, Kari, etc. (2\%) (Read usefully the Communal Development Plan of Ngaoui 2016). Essentially, the locality of Ngaoui has more than $2 / 3$ of the population of this administrative constituency. Although the Mbororo are geographically spread over the entire extent of the Ngaoui, they are demographically concentrated in the villages with pastoral vocation mentioned above. The favorable demographic backbone of the Mbororo is linked to a high rate of immigration, sedentarization and a high birth rate. Following the perspectives of Durkheim, the general idea here is that a large population has a moral density and sufficient electorate to play a subsequent political role. Likewise, the alibi of electoral competition leads political parties to rely primarily on majority ethnic groups. The structural assimilation of political parties refers to the proportional distribution of ethnic groups in party structures and nominations (Quoted by Mouiche, 2011, p.22; Mouiche, 2012). This integrating role of political parties has also been facilitated by the activism of MBOSCUDA, a new Mbororo social movement, which, through its sensitization acts, has awakened the political consciousness of the Mbororo (Mbebi Ndema, 2015).

The economic variable is another explanatory factor for the local political domination of the Mbororo. At this level, the field data indicate a contrast between the terminologies consecrated by international bodies and / or Cameroonian legislation to characterize them and their socio-economic status. In the world of social representations, the Mbororo do not see themselves as economically disadvantaged or vulnerable social groups. In this regard, the National Association for the Dignity of the Fulani Mbororo Community (ANDCP) challenges the miserable and marginal image of this Fulani fraction, projected by the entrepreneurs of the MBOSCUDA by finding it urgent, to attract the attention of the international community on "these villainous manipulations which tarnish the image of the whole community". Likewise, the Mbororo are also perceived by the Gbaya agricultural populations and the administrative authorities as being "the lungs of the rural Councils " of Ngaoui and the

\footnotetext{
${ }^{9}$ Read on these points, the circular letter of the Socio-cultural Association for Livestock Development and Agriculture in Cameroon (SODELCO aux Mbororo), p.6; read also Message to the international community from the ANDC.
} 
surrounding localities. In the state / society relationship, the Mbororo constitute the local ethnic fraction which occupies a position in the structure such that the structure acts in its favor (Bourdieu, 2000, p.238). Or which benefits from asymmetries of social position and social status (Messu, 2000 quoted by par Chazel, 1983, pp.369-393). The Mbororo produce wealth through cattle trade, the taxes that are issued to the Zoo technical and Veterinary Center (CZV and the significant revenues they generate. In this district, they have the advantage of having economic power. This financial influence makes them real local political interlocutors with which the central power must come to terms. The economic weight of the Mbororo is also perceptible during the financing of political activities. Several Islamic-Fulani economic operators were used to finance the political activities of the National Union for Democracy and Progress (NUDP) and the Cameroon's People Democratic Mouvment (CPDM) in Ngaoui. We can list among others: Bouba Labi, Abdourame Labi, Alhadji Idrissou, Alhadji Namali, Alhadji Bassoro, Alhadji kaka Kilbou, Alhadji Awane Adoum, Alhadji Salihou Midjiya (Interview on 05/07/2019 in Ngaoui). It is important to observe that active lobbying helps to protect economical activities in our democracies. On this basis, Grossman and Helpman developed a model that puts the motive of influence at the heart of the decision whether or not to contribute to a candidate's campaign or to the financing of a party's political activities (Quoted by Farvaque and Paty, 2009, p.92). In addition to their favourable demographic framework and economic weight, the new national and international legal context is favourable to "indigenous peoples".

3.2.2 The New National and International Politico-Legal Context Favourable to Indigenous Peoples

Cameroon is one of the states that have signed the United Nations Declaration on the Rights of Indigenous Peoples. From the perspective of social inclusion, the political liberalization of the 1990s in this state was marked by a constitutional reform dated January 18, 1996 which established a decentralized unitary state, recognized the rights of indigenous people and protected minorities. This guarantee of the rights of minorities and indigenous populations appears explicitly in the preamble of the Constitution. In addition, in Title X devoted to decentralized territorial collectivities, article 57 (2) indeed provides that the Regional Council which is the deliberative body of the region "must reflect the different sociological components of the region" (Mouiche, 2011: p. 12). Before this constitutional reform, the laws relating to the organization of municipal and legislative elections passed in the 1990s had already instituted this requirement of respect for "different sociological components" in the electoral districts, in particular article 5 paragraph 4 of law n ${ }^{\circ} 91 / 020$ of December 16 , 1991, fixing the conditions for the election of the parlementarian to the National Assembly and article 3 paragraph 2 of the law n ${ }^{\circ}$ 92/002 of August 14, 1992 fixing the conditions of elections of the municipal councillors. This notion of "sociological components" essentially boils down to "the different ethnic components of the population". This is the meaning attributed to it by Cameroonian litigants in the context of contentious appeals relating to municipal elections since 1996 (Ibid). Although influenced by the UN conception of indigenous people, the government of Cameroon has classified the Mbororo as "vulnerable populations" (Read Ngando Sandje, 2013/2: p.33; Also read Mouangue Kobila,2009: p.103). 


\section{Mll Macrothink}

Journal of Public Administration and Governance

ISSN 2161-7104

2021, Vol. 11, No. 1

The choice of this terminology is motivated by risks related to their environment and their way of life. In this context, they belong to a layer of so-called marginal populations which creates an exceptional protection regime and enhanced protection of their rights. This protection stems both from the desire for sedentarization of certain Mbororo families and respect for their traditional nomadic way of life: in the first case, the government of Cameroon is implementing its policy of national integration and sedentarization of the Mbororo on specific territories, through the creation of Mbororo chiefdoms or their integration into already existing chiefdoms. This is the case with the Ardorate of Sagba, a 2nd degree chiefdom, created in 1982 on the territory of the Kedjom Ketinguh chiefdom (Read on these points, Cameroon's response to the urgent appeal of the previous mandate holder, Mr. Rodolfo Stavenhagen, p. 27). In the second case, the government supervises nomadic groups with a view to ensuring their protection against roadblocks in particular and improving their access to schooling. A plan to assign nomadic teachers who would follow the Mbororo in their various transhumance is under study (Ibid). In this context, policies and programs taking into account the specific interests of the Mbororo are put in place. These include: the promotion of citizenship and access to civil status through the establishment of 600 birth certificates in 2006; support for micro-projects; improving hygiene and facilitating access to drinking water; the creation of health centres, and drug supply; strengthening access to education with the creation of schools in settled villages; the training of agents of State services in decentralized local communities, the management of citizenship and the establishment of inter-community social mediation. In other words, it is about strengthening the dynamic of sedentarization of the Mbororo.

The international recognition of the Mbororo as indigenous peoples also contributes to legal protection against abuses by national governments. This international consecration constitutes a legal basis for claiming humanitarian interference by the international community. The memorandum of the Central African Mbororo Fulani refugees in Cameroon and Tchad: communities in danger, Memorandum to the Cameroonian Government, to the Government of Tchad, humanitarian agencies, and the international community, addressed by Mr. Waziri Bibouba Housseini, President AIDSPC, Refugee in Ndjamena (Chad) and Mr. Aladji Ousmanou Alihou, Communication Officer AIDSPC, Refugee in Bertoua (Cameroon). Remains an example of transnational mobilization of Mbororo against national governments in the face of violations of their rights ${ }^{10}$. So, we can read:

\section{We, Foulanies-Mbororo (...), through our organization, the Association for the Integration and Social Development of the Mbororo Foulanies of the Central African Republic (AIDSPC), hereby inform you of the situation of the Central African Foulany, a minority community, marginalized and very often the first victims of the successive crises that our country has known".}

The transnational mobilization of the Mbororo within the framework of memorandums

\footnotetext{
10 The Central African Fulani Mbororo refugees in Cameroon and Chad: communities in danger, Memorandum to the Cameroonian Government, the Chadian Government, humanitarian agencies, and the international community, addressed by Mr. Waziri Bibouba Housseini, President AIDSPC, Refugee in Ndjamena (Chad) and Mr. Aladji Ousmanou Alihou, AIDSPC Communication Officer, Refugee in Bertoua (Cameroon).
} 
takes place in a context of the acceleration of the complex interdependence between societies and the blurring of the classic distinction between the internal and the external; because this is an analysis of the behavior of certain vulnerable social categories based on research into external influences affecting the nature of the political regimes of the states that host them (Sindjoun, 2001: 31). This is a consequence of the integration of international societies through international organizations such as the United Nations which exert structural pressure on States, in terms of recommendations, suggestions or sanctions (Ibid, p.26). The objective is to solicit humanitarian intervention from the international community for the framing of internal political excesses. The Mbororo articulate their demands globally and enjoy the international support of NGOs. Through its collaboration with international development agencies, this movement has created links with transnational human rights and minority organizations, such as Amnesty International, Survival International, Minority Rights Group International and the World Intellectual Property Organization. This international support attests to the vitality of the challenge of violations of the rights of the Mbororo that can be perpetrated by state agents. Furthermore, in accordance with the United Nations proclamation of the Decade of "Indigenous Peoples" (1995-2004), the MBOSCUDA movement has promoted the Mbororo as an "indigenous minority" whose cultural survival must be protected. Thanks to the active lobbying of these associations, the Mbororo are recognized by the State of Cameroon and by international organizations, especially the UN, as an indigenous (indigenous), minority and vulnerable ethnic group. This international status gives the Mbororo several advantages such as international protection, fulfillment, and their integration into the state apparatus, international aid and subsidies ${ }^{11}$. This made it possible to integrate the leaders of MBOSCUDA into government programs for the development of indigenous people in Cameroon. In 2005, the Economic and Social Council of the United Nations granted MBOSCUDA special consultative status" (Michaela, 2008: p.550-551).

\section{Conclusion}

The objective of this work was to study the unique socio-political trajectory of the Mbororo in Ngaoui Subdivision (Cameroon) which goes against the current paradigm of vulnerability and marginality enshrined in the abundant literature on this Fulani fraction. The change that began in the 1970s in a context marked by the boom in the cross-border livestock market in Ngaoui, the establishment of administrative services and accelerated by cross-border crime has established their sedentarization. This is achieved through the diversification of economic activities on the one hand, and the other hand by the erection of certain Mbororo clans into dominant aristocracy, which resulted in the seizure of traditional and local power in this community. The local political domination of the Mbororo in the locality of Ngaoui is due to the conjunction of several factors: their favourable demographic framework and the economic weight and the new national and international legal-political framework which is favourable to indigenous peoples. This socio-political trajectory of the Mbororo of Ngaoui contrasts very well with the definitional and identifying criteria of indigenous people

\footnotetext{
${ }^{11}$ According to the circular letter of the Socio-cultural Association for Livestock Development and Agriculture in Cameroon (SODELCO in Mbororo) and the message to the international community, this international aid does not really benefit the Mbororo community.
} 
enshrined in the World Bank and international law. These criteria appear to be understated in this study. This socio-political trajectory follows the objective criteria for assessing sedentarization and local domination. Unlike other categories of Mbororo from Cameroon, Tchad or Congo, those from the locality of Ngaoui no longer obey the criteria of marginality and vulnerability set out by the World Bank, international law and Cameroonian legislation. We are heading towards a paradigmatic shift in the Mbororo.

\section{Reference}

Adama, H. (2014). Migration norvégienne et protestantisme luthérien dans l'Adamaoua (Cameroun). De l'Adamawa à l'Adamaoua: Histoire, enjeux et perspectives pour le Nord-Cameroun, Paris, L'Harmattan, 67-91.

Zelao, A. (2017). Autorités traditionnelles et désir d'hégémonie dans le champ politique au Nord-Cameroun. Studia Politica. Romanian Political Science Review, 17(2), 355-376.

Assana, A. (2014). Memoranda et démocratisation dans l'Adamaoua (Cameroun): mutation des modes de participation politique ou entreprise d'instrumentalisation?. Droit et cultures. Revue internationale interdisciplinaire, (68), 213-246.

Assana. (2017). Démocratisation, ethnicité et recherche hégémonique locale au Cameroun: le cas de la région de l'Adamaoua, Thèse rédigée et soutenue publiquement pour l'obtention du Doctorat/Ph.D. en Science Politique, Université de Yaoundé, septembre.

Bellier, I. (2013). Peuples autochtones dans le monde. Les enjeux de la reconnaissance. L'Harmattan.

Bocquené, H., \& Ndoudi, O. (1986). Moi, un Mbororo: autobiographie de Oumarou Ndoudi, Peul nomade du Cameroun. KARTHALA Editions.

Bone Mbang Sodéa, J-L. (2005). L'EELC et l'évangélisation des Mbororo dans l'Adamaoua: 1958-2004, Mémoire de Maîtrise d'Histoire, Ngaoundéré, Université de Ngaoundéré.

Bonne Mbang Sodéa Jean-Louis, Owona Ndounda Nicolas, « De la religion patrimoniale au christianisme. Les mbororo chrétiens de l'Adamaoua : entre intégration et ostracisme », in Tiemeni Sigankwe, Nicholas Owona Ndounda (Coor.). (2019). Géopolitique du fait religieux au Cameroun, volume 8, numéro 8, pp.38-61.

Bourdieu, P. (2000). Les structures sociales de l'économie. Paris, Seuil.

Boutrais, J. (1994). Les Foulbé de l'Adamaoua et l'élevage: de l'idéologie pastorale à la pluri-activité (The Adamawa Fulani and Stock Raising: From Herding Ideology to Economic Diversification). Cahiers d'études africaines, 175-196.

Boutrais, J. (1999). Les savoirs pastoraux des Mbororo de l'Adamaoua; évolution et rapports au développement. Le pouvoir du savoir, de l'Arctique aux Tropiques. Paris: Karthala.

Burnham P. (1996). The Politics of Cultural Difference in Northern. International African Library, Edinburgh University Press, London. 


\section{Macrothink}

Journal of Public Administration and Governance ISSN 2161-7104 2021, Vol. 11, No. 1

Chazel, F. (1983). Pouvoir, structure et domination. Revue française de sociologie, 369-393. https://doi.org/10.2307/3321866

Davis, L. (1995). Opening political space in Cameroon: the ambiguous response of the Mbororo. Review of African Political Economy, 22(64), 213-228. https://doi.org/10.1080/03056249508704122

Décret N²013/332 du 13 septembre 2013 modifiant et complétant certaines dispositions du décret $\mathrm{n}^{\circ} 77 / 245$ du 15 juillet 1977, portant l'organisation des chefferies traditionnelles.

Djida Danga Raphael Roger. (1998-1999). Dynamique des marchés à la frontière Cameroun-R-C-A : le cas du marché de Ngaoui dans le Mbéré (Adamaoua Nord-Cameroun), mémoire présenté et soutenu publiquement en vue de l'obtention du diplôme de maîtrise.

Dognin, R. (1981). L'installation des Djafoun dans l'Adamaoua camerounais. La djakka chez les Peul de l'Adamaoua. Contribution de la recherche ethnologique à l'histoire des civilisations du Cameroun, ed. C. Tardits, 139-57.

Donfack Sokeng, L. (2001). Le droit des minorités et des peuples autochtones au Cameroun (Doctoral dissertation, Nantes).

Douffissa, A. (1993). L'élevage bovin dans le Mbéré (Adamoua camerounais).

Farvaque, É., \& Paty, S. (2009). Economie de la démocratie. De Boeck Supérieur. https://doi.org/10.3917/dbu.farva.2009.01

Fregosi René et Espana Rodrigo (coordinateur). (2009). Droits de l'homme et consolidation démocratique en Amérique du Sud, Ed., L'Harmattan, pp. 297-313.

Grosfoguel, R. (2004). Race and ethnicity or racialized ethnicities? Identities within global coloniality. Ethnicities, 4(3), 315-336. https://doi.org/10.1177/1468796804045237

Rocher, G. (1968). Introduction á la sociologie générale. Éd. HMH.

Hurault, J. (1964). Antagonisme de l'agriculture et de l'élevage sur les hauts plateaux de l'Adamawa (Cameroun): Le lamidat de Banyo. Études rurales, (15), 22-71. https://doi.org/10.3406/rural.1964.1142

Kamdem, P. (2017). Scolarisation et vulnérabilité: les enfants réfugiés centrafricains dans la région de 1'Est-Cameroun. Espace populations sociétés. Space populations societies, (2016/3). https://doi.org/10.4000/eps.7019

Lode, K. (1990). Appelés à la liberté: histoire de l'Eglise Evangélique Luthérienne de Cameroun. IMPROCEP éd..

Kossoumna Liba'a, N. (2008). De la mobilité à la sédentarisation: gestion des ressources naturelles et des territoires par les éleveurs Mbororo au Nord du Cameroun (Doctoral dissertation, UPV).

La lettre circulaire du Socio-cultural Association for Livestock Development and Agriculture in Cameroon (SODELCO aux Mbororo) et le message à la communauté internationale, ces 
aides internationales ne profitent pas véritablement à la communauté mbororo.

La lettre circulaire du Socio-cultural Association for Livestock Development and Agriculture in Cameroon (SODELCO aux Mbororo), p.6 ; lire également Message à la communauté internationale de 1 ANDC.

La lettre-circulaire $\mathrm{N}^{\circ} 00000831 / \mathrm{LC} / \mathrm{MINAT/SG/Dot} \mathrm{en} \mathrm{date} \mathrm{du} 11$ mai 2018.

Le Rapport du groupe de travail d'experts de la commission africaine des droits de l'homme et des peuples sur les populations autochtones/communautés autochtones, présenté en vertu de la "Résolution sur les droits des populations/communautés en Afrique », adoptée par la commission africaine des droits de l'homme et des peuples lors de sa 25ème session ordinaire, 2005 .

Le Rapport Socio-économique du Département du Mbere pour le compte de l'année 2018, 2019.

Les Peuls Mbororo centrafricains refugiés au Cameroun et au Tchad : des communautés en danger, Mémorandum à l'endroit du Gouvernement camerounais, du Gouvernement tchadien, des Agences humanitaires, et de la Communauté internationale, adressé par Monsieur Waziri Bibouba Housseini, Président AIDSPC, Réfugié à Ndjamena (Tchad) et Monsieur Aladji Ousmanou Alihou, Chargé de communication AIDSPC, Réfugié à Bertoua (Cameroun).

Manja, B. (2019). From nomadism to sedentarization: the case of the Mbororo in the Northwest Region of Cameroon. Thèse de doctorat, Anthropologie, Université de Yaounde I.

Mbebi Ndema Raymond Marcien. (2015). Nouveaux Mouvements Sociaux et Intégration Sociopolitique des minorités ethniques au Cameroun, Thèse présentée et soutenue publiquement pour l'obtention du Doctorat/Ph. D. en Science politique.

Pelican, M. (2008). Mbororo claims to regional citizenship and minority status in North-West Cameroon. Africa, 540-560. https://doi.org/10.3366/E0001972008000430

Mimche, H., \& Michaela, P. (2012). Quand les immigrants se font "'autochtones": dynamiques d'insertion des Mbororo et insécurité foncière à l'Ouest-Cameroun. in Pierre Kamdem et Martin Kuete (eds.), L'insécurité au Cameroun: mythe ou réalité ?,Paris, Iresma, pp.145-167.

Kobila, J. M. (2009). La protection des minorités et des peuples autochtones au Cameroun: entre reconnaissance interne contrastée et consécration universelle réaffirmée. Dianoïa.

Mouiche, I. (2012). Démocratisation et intégration sociopolitique des minorités ethniques au Cameroun: entre dogmatisme du principe majoritaire et centralité des partis politiques. CODESRIA, Conseil pour le développement de la recherche en sciences sociales en Afrique.

Mouiche, I. (2011). Les minorités ethniques et les défis de la représentation politique au Cameroun, (version provisoire),

Mouiche, I. (2013). Migration contemporaine, politique locale et construction de l'autochtonie au Cameroun: le cas des Pouakam du royaume bamoun. Verfassung und Recht 
in Übersee/Law and Politics in Africa, Asia and Latin America, 285-302. https://doi.org/10.5771/0506-7286-2013-3-285

Sandje, R. N. (2013). Politiques foncières et autochtonie au Cameroun. Can. JL \& Soc., 28, 315. https://doi.org/10.1017/cls.2013.30

Leservoisier, O. (2009). Démocratisation et renégociations sociales. Politique africaine, (2), 24-43. https://doi.org/10.3917/polaf.114.0024

Plan Communal de développement de Ngaoui 2016.

Quijano, A. (2007). «Race» et colonialité du pouvoir. Mouvements, (3), 111-118. https://doi.org/10.3917/mouv.051.0111

Réponse du Cameroun à l'appel urgent du précédent titulaire du mandat, M. Rodolfo Stavenhagen.

Issa, S. (2004). L'embuscade sur les routes des abords sud du Lac Tchad. Politique africaine, (2), 82-104.

Issa, S. (2006). La prise d'otages aux confins du Cameroun, de la Centrafrique et du Tchad: une nouvelle modalité du banditisme transfrontalier. Polis/Revue Camerounaise de Science Politique, 13(1-2), 119-146.

Schuft, L. (2010). Couples 'métropolitain'-'polynésien'à Tahiti. Enjeux de l'ethnicité, du genre et du statut socioéconomique dans un contexte postcolonial (Doctoral dissertation, Université Nice Sophia Antipolis).

Schulte-Tenckhoff. (1997). La question des peuples autochtones, coll. Axes Savoirs, Bruylant, Bruxelles, LGDJ.

Seignobos, C. (IRD). (2011). Les Mbororo du Lom-pangar. Mission sociologique (Banque mondiale/EDC), 23 février.

Sindjoun, L. (2001). La loyauté démocratique dans les relations internationales: sociologie des normes de civilité internationale. Études internationales, 32(1), 31-50. https://doi.org/10.7202/704255ar

Taguem, F. G. L. (2014). «L'Adamaoua dans l'entre deux : Trajectoire historique d'une région en mutation perpétuelle », in Hamadou Adama (dir.), De l'Adamawa à l'Adamaoua. Histoire, enjeux et perspectives pour le Nord-Cameroun, Paris, L'Harmattan, pp.43-65.

Tidjani, I. (2018). La mobilité pastorale en République centrafricaine : une stratégie d'adaptation et de survie, thèse de doctorat en sciences économiques, préparée et soutenue publiquement le, Université de Lille, le 05 décembre

Tidjani, I. (2015). Impact de la crise politico-militaire de 2013-2014 sur le pastoralisme et la transhumance en République centrafricaine. Rapport d'Études socio-anthropologiques du conflit, novembre 2014/janvier. 


\section{Macrothink}

Journal of Public Administration and Governance ISSN 2161-7104 2021, Vol. 11, No. 1

Genieys, W., Smith, A., Baraize, F., Faure, A., \& Négrier, E. (2000). Le pouvoir local en débats. Pour une sociologie du rapport entre leadership et territoire. Pôle Sud-Revue de science politique de l'Europe méridionale, (13), 103-119. https://doi.org/10.3406/pole.2000.1090

\section{Copyright Disclaimer}

Copyright for this article is retained by the author(s), with first publication rights granted to the journal.

This is an open-access article distributed under the terms and conditions of the Creative Commons Attribution license (http://creativecommons.org/licenses/by/4.0/). 